\title{
Architect Perceptions of Engineered Wood Products: An Exploratory Study of Selected Countries in Central and Southeast Europe
}

\author{
Manja K. Kuzman ${ }^{1}$, Sanela Klarić ${ }^{2}$, Andreja Pirc Barčić ${ }^{3}$, Richard P. Vlosky \\ Marija M. Janakieska ${ }^{5}$, Petra Grošelj ${ }^{6 *}$ \\ ${ }^{1}$ University of Ljubljana, Department of Wood Science and Technology, Biotechnical Faculty, Jamnikarjeva \\ 101, 1000 Ljubljana, Slovenia [email: manja.kuzman@bf.uni-lj.si] \\ ${ }^{2}$ International Burch University, Francuske revolucije bb, Ilidža \\ 71000 Sarajevo, Bosnia and Herzegovina [email: sanela.klaric@ibu.edu.ba] \\ ${ }^{3}$ University of Zagreb, Faculty of Forestry, Svetošimunska cesta 25, 10000 Zagreb, Croatia \\ [Email: apirc@sumfak.hr] \\ ${ }^{4}$ Crosby Land \& Resources Endowed Professor and Director, Louisiana Forest Products Development Center, \\ Louisiana State University, Baton Rouge, Louisiana 70803, USA [email: RVlosky@agcenter.lsu.edu] \\ ${ }^{5}$ Faculty of Civil Engineering, Department on Concrete and Timber Structures, University "Sts. Cyril \& \\ Methodius", Skopje, Macedonia, [email:marija_mls@hotmail.com] \\ ${ }^{6}$ University of Ljubljana, Biotechnical Faculty, Jamnikarjeva 101, 1000 Ljubljana, Slovenia [email: \\ petra.groselj@bf.uni-lj.si] \\ *corresponding author
}

\begin{abstract}
The wood industries in Slovenia, Croatia, Bosnia and Hercegovina $(\mathrm{BiH})$ and Macedonia have a long tradition of producing a wide range of products. $\mathrm{BiH}$ and Macedonia have similar forest sectors and both countries have experienced similar problems in the manufacturing, sale and use of wood-based products in recent years due to the global financial crisis and resulting national economic challenges. Despite having a long and prosperous history, over the past two decades, the wood products sectors in these four countries have faced a steady decline in profitability, the ability to add value through downstream manufacturing, and overall competitiveness.

Engineered wood products (EWPs) are structural building materials that have been used since the early 1980s as replacements for, or in conjunction with, concrete and steel. In this study, we compare architect attitudes, awareness and preferences regarding the use of EWPs between these four countries. The study is based on a sample of 373 architects using on-line surveys. Results suggest that there is a positive perception regarding the use of wood in general in all countries, with the majority of respondents believing that wood use will increase in the future. However, specific to EWPs, differences were found in familiarity and knowledge of potential applications in timber-based construction. Results provide indicators of knowledge gaps between respondents and, conversely, where awareness and willingness to use EWPs exist. These findings can have implications for market opportunities, identifying barriers to EWPs adoption, and content for workshops, seminars, and other outreach mechanisms for architects.
\end{abstract}

Keywords: engineered wood products (EWPs), architects, timber construction, material specification, market potential, Central and Southeast Europe 


\section{Introduction}

Growing environmental awareness presents one of the most important advantages of wood as a construction material, where the choice is motivated by the fact that wood is a renewable material and that its use reduces $\mathrm{CO}^{2}$ emissions - provided that the raw material is harvested in forests where sustainable forestry is practiced including replanting and adoption of management plans [1]. The introduction of new products in the construction sector, however, is generally met with hesitation, low awareness, and high uncertainty in the marketplace; therefore, the communication of information is vital to market success [2-4]. There are demand stimulants: efficiency improvements in existing buildings and renovations; improved specialized training; efforts to make the sector more attractive in terms of research and innovation; and a greater active uptake of new technologies.

During the 2000s, pressure has increased at local, regional, and national levels to find a balance in using forest resources to enhance economic, environmental, social, and cultural benefits $[5,6]$. Simultaneously, the role of wood in the modern bioeconomy, and the global emphasis on enhancing sustainable development via increased renewable resource utilization has stimulated large-scale demand for wood products for many end-users, as well as specifying wood by architects [7, 8]. In Europe, the wood products sector plays a pivotal role in the development of a sustainable society, where economic, environmental, social and cultural aspects of using natural resources are taken into account [9]. In this context, wood-based products are also the most preferred building materials in terms of energy-efficient construction $[10,11]$. Use of wood is increasingly being considered as a substitute for steel or concrete by contractors, architects and construction companies because wood is renewable and often results in lower installed costs.

The evolving preferences of those who specify the construction materials may be greatly affected by their own notions as to what drives value in terms of the consumption of wood products [12]. There are four key actor groups in the construction value chain that influence the construction process after a project has been commissioned by a person, organization, or an authority $[13,14]$ :

1. The developer organizes and manages the process, and has the overall responsibility for design, specification, and economic conditions.

2. Mandated by the developer, consultants, including architects, engineers, and project managers offer expert services for the design and management of the project.

3. The main contractor, together with numerous sub-contractors, is responsible for the realization of the project.

4. Finally, numerous material suppliers are responsible for supplying all the materials, components, and machinery for the building project.

Many building material selection choices are guided by a desire to minimize their negative impacts, either on the occupants or on the environment [15]. There is no doubt that the process of learning about the actual options available in material selection has a tremendous bearing on the actions that professionals take, and the attitudes that they hold throughout their careers. This is no different in the field of design, where, among other subjects, architects and structural engineers are constantly acquiring knowledge about the use of various structural materials, products, and systems [16]. It is this information that forms the basis of most decisions pertaining to the specification of materials for use in structural building applications. To specifiers such as architects, new materials present both opportunities and risks. While opportunities derive from new or improved technical performance or aesthetic qualities, risks lie in the lack of design or manufacturing experiences [17]. 


\subsection{Engineered Wood Products (EWPs)}

In the past two decades, a new class of structural wood products has been developed to form the basis for a range of building solutions that are increasingly functional, based on a combination of performance and sustainability characteristics. This has been possible because of new industrial processes that provide increased dimensions and superior engineering properties for structural products that can use manufacturing residues and lower-grade and smaller diameter trees as feedstock. The result is a category of products broadly known as engineered wood products (EWPs) which are increasingly be adopted in architectural design and building applications $[12,18]$.

Much of the information in the literature on forest sector sustainability is grounded on a diverse set of data related to, for example, specific forest industry products, sustainability issues or stakeholder groups [19-22]. Less focus has been placed on uses of EWPs, generally in the context of structural applications from builder perspectives. In addition, some studies have been conducted on related topics such as consumer acceptance of wood-plastic composites [23], perspectives of use of wood-based products in green buildings [24], and success factors and barriers for innovation diffusion of new wood-based materials [25].

A number of studies have also been conducted on barriers and challenges of increased wood use in the non-residential sector, with a particular focus on wood as a structural material [3, 16, 26-29]. Generally, in Northern Europe, government building code, project developers, or building contractors were found to be the most important influencers regarding the choice of building material, while in the Alpine Region [30], South Central Europe [31] and Southern Europe, architects were identified as the most influential decision maker [32, 33].

To date, the literature is lacking in studies that specifically examine a comprehensive understanding of architect perceptions related to EWPs. As such, we selected architects as the key target group in this research effort as they are key decision makers in the selection of materials in the construction sector. In addition, some studies found architects to be environmentally conscious specifiers of construction materials, and, as such, are an important target group for research particularly as environmental and sustainability issues are becoming more salient issues generally [34-36].

The construction industry is the consumer of EWPs. Some of the key products in this family of materials are shown in Table 1.

Table 1. Engineered Wood Products (EWPs)

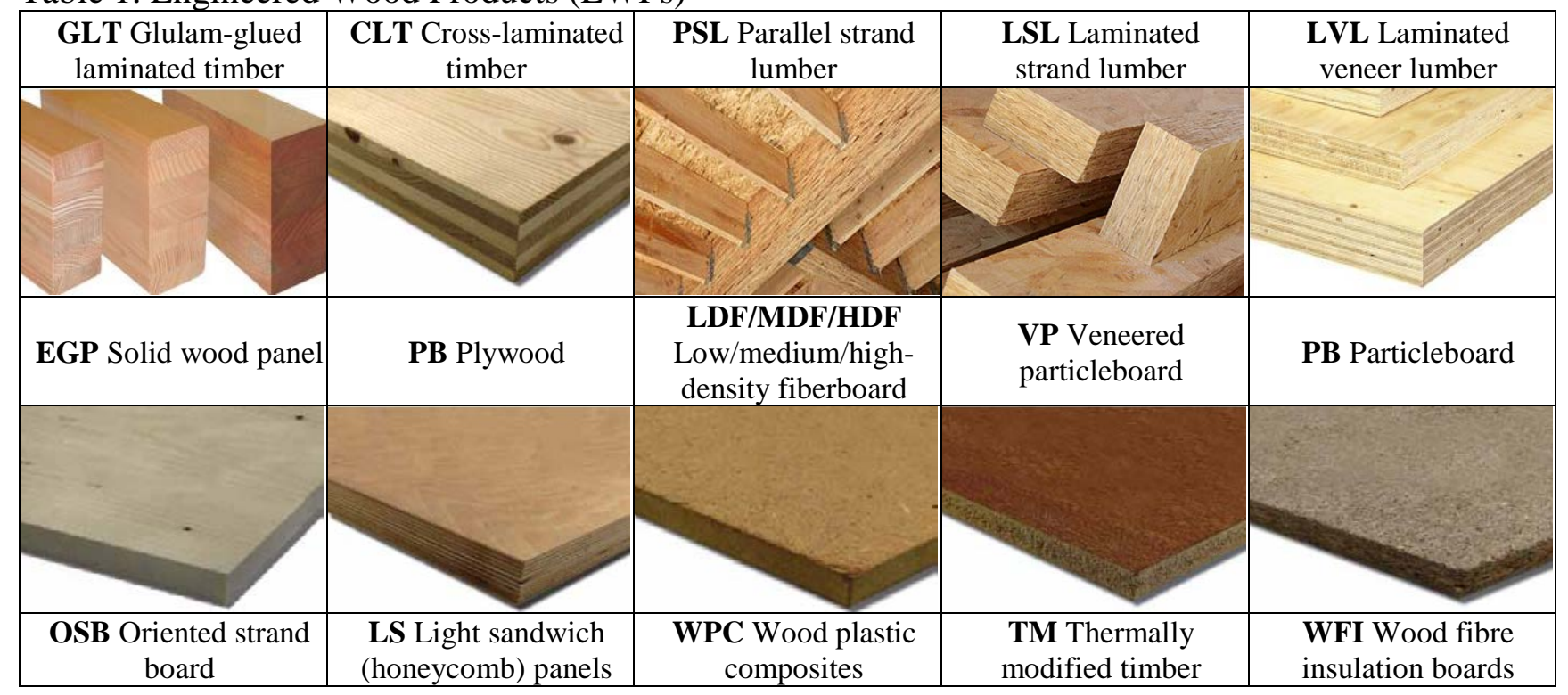




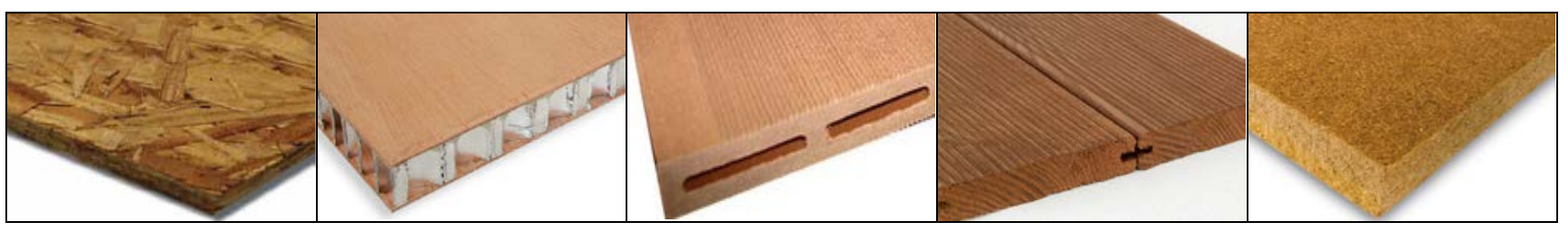

\subsection{Study Geographical Countries}

In Southeast European countries, including Slovenia, Croatia, BiH, and Macedonia, the wood sector has a very long tradition and has always been an important segment of each country's economy. To get a better picture of the importance of the forest sector in these countries, some additional information regarding relevant forestry statistics are presented in Table 2.

Table 2. Slovenia, BiH, Croatia and Macedonia - Selected Forestry Data, 2015 (Government Statistics)

\begin{tabular}{|c|c|c|c|c|}
\hline & Slovenia & Croatia & $\mathbf{B i H}$ & Macedonia \\
\hline $\begin{array}{l}\text { Surface area of } \\
\text { forested land (ha) }\end{array}$ & $1.18 \cdot 10^{6}$ & $2.76 \cdot 10^{6}$ & $3.23 \cdot 10^{6}$ & $1.09 \cdot 10^{6}$ \\
\hline Forested area (\%) & $62 \%$ & $86 \%$ & $56 \%$ & $42 \%$ \\
\hline $\begin{array}{l}\text { Number of naturally } \\
\text { occurring tree } \\
\text { species }\end{array}$ & 71 & 94 & 75 & 319 \\
\hline Growing stock $\left(\mathrm{m}^{3}\right)$ & $346.10 \cdot 10^{6}$ & $418.60 \cdot 10^{6}$ & $201 \cdot 10^{6}$ & $75.94 \cdot 10^{6}$ \\
\hline $\begin{array}{l}\text { Annual growth of } \\
\text { growing stock } \\
\text { (m³ forest) }\end{array}$ & $8.59 \cdot 10^{6}$ & $10.14 \cdot 10^{6}$ & $7.48 \cdot 10^{6}$ & $1.62 \cdot 10^{6}$ \\
\hline $\begin{array}{l}\text { Annual harvest }\left(\mathrm{m}^{3}\right. \\
\text { forest) }\end{array}$ & $6.19 \cdot 10^{6}$ & $5.86 \cdot 10^{6}$ & $4.70 \cdot 10^{6}$ & $1.09 \cdot 10^{6}$ \\
\hline Hardwoods $\left(\mathrm{m}^{3}\right)$ & $3.35 \cdot 10^{6}$ & $4.95 \cdot 10^{6}$ & $1.60 \cdot 10^{6}$ & - \\
\hline $\begin{array}{l}\text { Softwoods }\left(m^{3}\right) \\
\text { Sawn wood }\end{array}$ & $2.84 \cdot 10^{6}$ & $0.90 \cdot 10^{6}$ & $3.10 \cdot 10^{6}$ & - \\
\hline $\begin{array}{l}\text { Consumption Per } \\
\text { Capita }\left(\mathrm{m}^{3} / \mathrm{y}\right)\end{array}$ & 0.4 & 0.1 & 0.2 & 0.1 \\
\hline
\end{tabular}

Unfortunately, in the last 2-3 decades these countries have experienced many economic and social changes that either directly or indirectly influenced the wood industry sector. These markets are attracting domestic as well as foreign investors. In recent years, particularly in Slovenia, there has been a concerted national effort to increase the level of wood used in residential construction, in part as a means to lower the carbon footprint of these buildings [10]. There are also initiatives in Croatia and $\mathrm{BiH}$, but primarily at the local level, mostly related to wood-cluster development in Croatia, and initiatives by local architects who are willing to explore the advantages of using wood to develop unique designs for residential and tourist buildings in $\mathrm{BiH}$. Wood construction in Slovenia is transitioning from a formative to a growth phase, while in Croatia, $\mathrm{BiH}$ and Macedonia it is still in the formative phase [33, 37].

Timber for residential building structures has a market share of about $10 \%$ in Slovenia [31], but is almost non-existent in Croatia and BiH. In Macedonia, wood is often used only for small residential houses, or limited to roof construction or canopies; although there has been recent interest in using wood on the façades of buildings and in the interior applications due to demand for enhanced aesthetic appearance. Macedonian architects are trying to implement wood in their designs, but only as a decorative material with the most used constructive material being concrete. 
In Slovenia, since 2014, there has been a program to promote the use of wood in general, though not specifically for the construction of multi-storey buildings. Slovenia, also in 2014, adopted the Green Public Procurement (GPP) where it is generally required that $30 \%$ of inbuilt material (by volume) must be timber or timber-based (50\% of this can be substituted by products with EcoLabels I or III) [33]. Table 3 identifies the key differences in wood-based construction in Slovenia, Croatia, $\mathrm{BiH}$ and Macedonia. In Croatia and $\mathrm{BiH}$ there are some incentives supported mostly by donor-funded projects, with no consistent active promotion organized by local stakeholders or industry. Further, activities in $\mathrm{BiH}$ generally lack any strategic approach supported by the government or professional associations. In Croatia there was formed in 2007 a successful advertising campaign, 'Wood is First', run as a joint initiative of the Croatian Chamber of Economy, the Ministry of Agriculture and the Croatian Forests to increase the use of wood and strengthen the competitiveness of domestic wood processors. In Macedonia there have been no initiatives supporting the use of wood. We suggest that any systematic comprehensive promotional campaign for the increased use of wood in structural applications should focus on its differentiating characteristics vis-à-vis steel and/or concrete, particularly it's close relationship to both societal benefits, (e.g. less energy intensive to manufacture) and environmental benefits (e.g. carbon sequestration) [38].

Table 3. Wood-based Construction in Slovenia, Croatia, BiH and Macedonia

\begin{tabular}{|c|c|c|c|c|}
\hline & Slovenia & Croatia & BiH & Macedonia \\
\hline $\begin{array}{l}\text { Share of detached } \\
\text { houses in residential } \\
\text { construction [\%] }\end{array}$ & $40 \%$ & n.a. & n.a & n.a \\
\hline $\begin{array}{l}\text { Market share of wood } \\
\text { in detached houses } \\
\text { [\%] }\end{array}$ & $10 \%$ & n.a. & n.a. & $2-5$ \\
\hline $\begin{array}{l}\text { Market share of } \\
\text { wood in multi-story } \\
\text { construction [\%] }\end{array}$ & - & - & n.a. & - \\
\hline $\begin{array}{l}\text { Maximum number of } \\
\text { floors allowed from } \\
\text { wood, with sprinklers, } \\
\text { in } 2014\end{array}$ & $\leq 5^{1}$ & - & no limit & 3 \\
\hline $\begin{array}{l}\text { Key wood } \\
\text { construction } \\
\text { techniques }\end{array}$ & $\begin{array}{l}\text { Timber- } \\
\text { panel } \\
\text { - Timber- } \\
\text { frame } \\
\text { - Massive- } \\
\text { timber }\end{array}$ & $\begin{array}{ll}\text { - } & \text { Timber } \\
& \text { panel } \\
\text { - } & \text { Traditional } \\
& \text { timber- } \\
& \text { frame } \\
\text { - } & \text { Massive- } \\
\text { timber }\end{array}$ & $\begin{array}{ll}\bullet & \text { Timber } \\
& \text { panel } \\
\bullet & \text { Traditional } \\
& \text { timber- } \\
& \text { frame } \\
\bullet & \text { Massive- } \\
\text { timber }\end{array}$ & $\begin{array}{ll}\text { - } & \text { Timber } \\
& \text { panel } \\
\text { - } & \text { Traditional } \\
\text { timber- } \\
\text { frame } \\
\text { - } \\
\text { Massive- } \\
\text { timber }\end{array}$ \\
\hline $\begin{array}{l}\text { Organizations } \\
\text { promoting wood at } \\
\text { national levels }\end{array}$ & $\begin{array}{l}\text { University of } \\
\text { Ljubljana, } \\
\text { Biotechnical } \\
\text { faculty, } \\
\text { department of } \\
\text { wood science and } \\
\text { technology, Wood } \\
\text { Industry Cluster, } \\
\text { The Furniture and } \\
\text { Wood-Processing } \\
\text { Industry } \\
\text { Association,Wood } \\
\text { Industry } \\
\text { Directorate }\end{array}$ & $\begin{array}{l}\text { Faculty of Forestry } \\
\text { University of } \\
\text { Zagreb, Croatian } \\
\text { Wood Cluster, } \\
\text { Wood Cluster } \\
\text { Vukovar-Srijem } \\
\text { County, } \\
\text { Croatian Chamber } \\
\text { of Economics, } \\
\text { Croatian } \\
\text { Competitiveness } \\
\text { Cluster for Wood } \\
\text { Processing }\end{array}$ & $\begin{array}{l}\text { Foreign Trade } \\
\text { Chamber of BiH- } \\
\text { association for wood } \\
\text { industry and forestry, } \\
\text { University of } \\
\text { Sarajevo, Faculty of } \\
\text { Forestry and } \\
\text { Mechanical Faculty } \\
\text { Faculty of Forestry } \\
\text { University of Banja } \\
\text { Luka }\end{array}$ & $\begin{array}{l}\text { University "Ss. Cyril } \\
\text { and Methodius", } \\
\text { Faculty of Civil } \\
\text { Engineering - Skopje } \\
\text { Building companies }\end{array}$ \\
\hline
\end{tabular}




\begin{tabular}{|l|l|l|l|l|}
\hline $\begin{array}{l}\text { Sawn wood } \\
\text { consumption per } \\
\text { capita }\left[\mathrm{m}^{3} / \mathrm{y}\right]\end{array}$ & 0.4 & 0.1 & 0.2 & 0.1 \\
\hline
\end{tabular}

In general, architects in Slovenia, Croatia, $\mathrm{BiH}$ and Macedonia have a positive attitude to timber buildings mainly due to environmental performance, but their attitudes towards concrete, brick and steel are traditionally more favourable with regard to structural integrity and fire resistance. The Wood Promotion Network (Table 3. - section Organizations promoting wood at national levels), has consistently reported that steel and concrete have made significant gains against wood in residential construction [31, 39, 40].

We suggest that the absence of comprehensive promotional of the wood sector can be significantly explained by the lack of understanding by the aforementioned members of the wood value chain from the forest to building construction. In this research, we test the level of understanding, awareness, and potential use of EWP technologies for structural and nonstructural building applications from the perspectives of architects, an area that has not previously been researched to any significant degree.

\section{THE STUDY}

\subsection{Objectives}

The overarching goal of this study is to identify architects perceptions regarding potential advantages/benefits and disadvantages/challenges in specifying EWPs. Based on these perceptions, we hope to identify communication mechanisms and messaging to increase architect understanding of EWPs. Changing specifier preferences regarding the positive attributes of EWPs may greatly affect the market structures for wood products that, in turn, impact demand, supply, opportunities for manufacturers, increasing employment, and overall local, regional, and national economic development.

\subsection{Methods}

A survey questionnaire was constructed and developed by an international group of architects, including the first author of this paper, a certified architect. The study methods included a two-stage survey; in the first stage, personal interviews were conducted, and then, based on input from these in-person interviews, the second stage an exploratory web-based survey was designed. The survey questionnaire was in English.

The target population of the survey included practicing architects, with lists complied from members of professional architect societies and associations: in Slovenia the Chamber of Architecture and Spatial Planning of Slovenia; in Croatia, the Croatian Chamber of Architects, in $\mathrm{BiH}$ the Association of Architects in Bosnia and Herzegovina; and in Macedonia, the Chamber of Certified Architects and Certified Engineers of the Republic of Macedonia.

Respondent data were collected through the on-line survey (the instrument was programmed in 1ka, a free web survey software developed by the Centre for Social Informatics at Faculty of Social Sciences, University of Ljubljana); random sampling of these association populations was used. Based upon similar studies [27, 29, 35, 41] a response rate of $15-35 \%$ is considered adequate for analytical purposes for business/corporate surveys. Taking into account an expected response rate within this range and a sampling error of 10\% [42] we sent out 320 questionnaires for each country - in total, 1,920 questionnaires. In Slovenia, $\mathrm{BiH}$ and Croatia, the survey process took place from late November 2016 to mid-January 2017. Two email survey reminders followed the initial mailing. The first reminder was sent one week after the original mailing and the second two weeks after the first reminder. We received 92 valid responses from Slovenia, 104 from Croatia, 86 from Bosnia and Herzegovina and 91 from Macedonia, for a total of 373 responses. Taking into account non-deliverables (e.g., invalid emails addresses or out-of-business firms); the response rates were $29 \%$ for Slovenia, $33 \%$ for 
Croatia, 27\% for Bosnia and 28\% for Macedonia. Although the reasons for low response rates are unknown for this study, often, the main reasons for non-participation in surveys are nonappealing survey topic, or the length of the questionnaire [43].

The questionnaire was divided into four parts. The first part contained questions about general perceptions and familiarity of architects with EWPs. The second part covered questions regarding their specifications of non-load and load-bearing systems, followed by the third part with questions on information sources and information needs of architects. The last part included demographic questions about respondent gender, country, profession and experience.

The statistical software SPSS 21.0 was used for data analysis. The Fisher's Exact Test was used to compare results between countries. When ranking the familiarity and characteristics of EWPs, the Modified Borda Count [44] was used. In this case, each respondent has to choose 5 (or 3) top options and rank these options in order of familiarity. Likert-type response scales, ranging from not important (1) to important (3), were used when asking about the importance of different ways of getting information about EWPs. We used Spearman's rank correlation coefficient as a nonparametric measure of dependence between the ranking of the years of professional experiences and the importance of architects' associations as a source of information.

\section{RESULTS AND DISCUSSION}

About $90 \%$ of all respondents work with architecture, followed by $5 \%$ of respondents working with building construction, while the remainder work in project management, interior design and structural engineering. Respondents had an average of 15-25 years of experience in Slovenia, and 5-15 years of experience in Croatia, $\mathrm{BiH}$ and Macedonia. In Slovenia $50 \%$ of respondents were men and 50\% women. In Croatia $46 \%$ of respondents were men and $54 \%$ women, $45 \%$ of respondents from $\mathrm{BiH}$ were men and 55\% were women and in Macedonia 38\% men and $62 \%$ women.

\subsection{General perceptions and familiarity of EWPs}

From the list provided, including photos, respondents were asked to identify which EWPs they were most familiar with; the possible selection products are listed in Table 4. The cells reflecting a percentage higher than $80 \%$ are coloured orange. In general, the overall familiarity with EWPs is relatively high.

The most common EWP familiarity in all four countries are structural GLT, SWP, PW, OSB - over $90 \%$ if respondents from all countries note familiarity with these products. $\mathrm{LDF} / \mathrm{MDF} / \mathrm{HDF} \mathrm{VP}$ and $\mathrm{PB}$ are also well known by respondents in all countries. The proportion of familiarity differs significantly among the countries for CLT $(p=0.003$, Fisher exact test), LVL ( $p=0.049$, Fisher exact test), LS ( $p=0.003$, Fisher exact test), WPC ( $p=0.005$, Fisher exact test) and WFI ( $\mathrm{p}=0.006$, Fisher exact test). Less known are PSL and LSL with similar proportions between countries by LSL and significant difference between countries by PSL ( $\mathrm{p}=0.006$, Fisher exact test).

Table 4. Respondent familiarity with EWPs

\begin{tabular}{|c|c|c|c|c|c|c|c|c|}
\hline & \multicolumn{2}{|c|}{ SLO } & \multicolumn{2}{|c|}{ CRO } & \multicolumn{2}{|c|}{ BiH } & \multicolumn{2}{|c|}{$\mathbf{M K}$} \\
\hline & No & Yes & No & Yes & No & Yes & No & Yes \\
\hline \multirow{2}{*}{ GLT Glued-laminated timber } & 1 & 91 & 6 & 98 & 5 & 81 & 6 & 85 \\
\hline & $1,1 \%$ & $98,9 \%$ & $5,8 \%$ & $94,2 \%$ & $5,8 \%$ & $94,2 \%$ & $6,6 \%$ & $93,4 \%$ \\
\hline \multirow{2}{*}{ CLT Cross-laminated timber } & 2 & 90 & 32 & 72 & 11 & 75 & 18 & 73 \\
\hline & $2,2 \%$ & $97,8 \%$ & $30,8 \%$ & $69,2 \%$ & $12,8 \%$ & $87,2 \%$ & $19,8 \%$ & $80,2 \%$ \\
\hline \multirow{2}{*}{ PSL Parallel strand lumber } & 40 & 52 & 66 & 38 & 29 & 57 & 25 & 66 \\
\hline & $43,5 \%$ & $56,5 \%$ & $63,5 \%$ & $36,5 \%$ & $33,7 \%$ & $66,3 \%$ & $27,5 \%$ & $72,5 \%$ \\
\hline
\end{tabular}




\begin{tabular}{|c|c|c|c|c|c|c|c|c|}
\hline LSL Laminated strand lumber & $\begin{array}{c}52 \\
56,5 \% \\
\end{array}$ & $\begin{array}{c}40 \\
43,5 \% \\
\end{array}$ & $\begin{array}{c}63 \\
60,6 \% \\
\end{array}$ & $\begin{array}{c}41 \\
39,4 \% \\
\end{array}$ & $\begin{array}{c}37 \\
43,0 \% \\
\end{array}$ & $\begin{array}{c}49 \\
57,0 \% \\
\end{array}$ & $\begin{array}{c}37 \\
40,7 \% \\
\end{array}$ & $\begin{array}{c}54 \\
59,3 \% \\
\end{array}$ \\
\hline \multirow{2}{*}{ LVL Laminated veneer lumber } & 6 & 86 & 28 & 76 & 26 & 60 & 23 & 68 \\
\hline & $6,5 \%$ & $93,5 \%$ & $26,9 \%$ & $73,1 \%$ & $30,2 \%$ & $69,8 \%$ & $25,3 \%$ & $74,7 \%$ \\
\hline \multirow{2}{*}{ SWP Solid wood panel } & 3 & 89 & 9 & 95 & 6 & 80 & 6 & 85 \\
\hline & $3,3 \%$ & $96,7 \%$ & $8,7 \%$ & $91,3 \%$ & $7,0 \%$ & $93,0 \%$ & $6,6 \%$ & $93,4 \%$ \\
\hline \multirow{2}{*}{ PW Plywood board } & 0 & 92 & 6 & 98 & 2 & 84 & 7 & 84 \\
\hline & $0,0 \%$ & $100,0 \%$ & $5,8 \%$ & $94,2 \%$ & $2,3 \%$ & $97,7 \%$ & $7,7 \%$ & $92,3 \%$ \\
\hline \multirow{2}{*}{ LDF/MDF/HDF fiberboards } & 3 & 89 & 3 & 101 & 2 & 84 & 13 & 78 \\
\hline & $3,3 \%$ & $96,7 \%$ & $2,9 \%$ & $97,1 \%$ & $2,3 \%$ & $97,7 \%$ & $14,3 \%$ & $85,7 \%$ \\
\hline \multirow{2}{*}{ VP Veneered particleboard } & 3 & 89 & 9 & 95 & 13 & 73 & 17 & 74 \\
\hline & $3,3 \%$ & $96,7 \%$ & $8,7 \%$ & $91,3 \%$ & $15,1 \%$ & $84,9 \%$ & $18,7 \%$ & $81,3 \%$ \\
\hline \multirow{2}{*}{ PB Particleboard } & 6 & 86 & 19 & 85 & 8 & 78 & 18 & 73 \\
\hline & $6,5 \%$ & $93,5 \%$ & $18,3 \%$ & $81,7 \%$ & $9,3 \%$ & $90,7 \%$ & $19,8 \%$ & $80,2 \%$ \\
\hline \multirow{2}{*}{ OSB Oriented strand boards } & 3 & 89 & 4 & 100 & 5 & 81 & 3 & 88 \\
\hline & $3,3 \%$ & $96,7 \%$ & $3,8 \%$ & $96,2 \%$ & $5,8 \%$ & $94,2 \%$ & $3,3 \%$ & $96,7 \%$ \\
\hline \multirow{2}{*}{$\begin{array}{l}\text { LS Light sandwich } \\
\text { (honeycumb) panels }\end{array}$} & 14 & 78 & 13 & 91 & 24 & 62 & 40 & 51 \\
\hline & $15,2 \%$ & $84,8 \%$ & $12,5 \%$ & $87,5 \%$ & $27,9 \%$ & $72,1 \%$ & $44,0 \%$ & $56,0 \%$ \\
\hline \multirow{2}{*}{ WPC Wood plastic composites } & 6 & 86 & 19 & 85 & 32 & 54 & 28 & 63 \\
\hline & $6,5 \%$ & $93,5 \%$ & $18,3 \%$ & $81,7 \%$ & $37,2 \%$ & $62,8 \%$ & $30,8 \%$ & $69,2 \%$ \\
\hline \multirow{2}{*}{ TM Thermally modified wood } & 3 & 89 & 25 & 79 & 15 & 71 & 9 & 82 \\
\hline & $3,3 \%$ & $96,7 \%$ & $24,0 \%$ & $76,0 \%$ & $17,4 \%$ & $82,6 \%$ & $9,9 \%$ & $90,1 \%$ \\
\hline \multirow{2}{*}{$\begin{array}{l}\text { WFI Wood fibre insulation } \\
\text { boards }\end{array}$} & 9 & 83 & 44 & 60 & 36 & 50 & 31 & 60 \\
\hline & $9,8 \%$ & $90,2 \%$ & $42,3 \%$ & $57,7 \%$ & $41,9 \%$ & $58,1 \%$ & $34,1 \%$ & $65,9 \%$ \\
\hline
\end{tabular}

Respondents also selected the five most familiar EWPs. We used a method called the Modified Borda count, where the most familiar EWP gets 5 points, the second most familiar 4 points... and the fifth most familiar, 1 point. The EWP with the highest sum of points was placed first. As seen in Table 5, the first five ranked EWP for each country are coloured orange. In Slovenia, GLT is in the first place, followed by CLT, OSB, PW and SWP. In Croatia, OSB is first, followed by FB, GLT, and then in $4^{\text {th }}$ and $5^{\text {th }}$ place PW and SWP (the same as in Slovenia). In BiH, GLT is ranked first, followed by OSB and PW, and in Macedonia OSB is ranked first, followed PW and GLT.

Table 5. Respondent Familiarity with Top 5 Ranked EWPs

\begin{tabular}{|c|c|c|c|c|c|c|c|c|c|c|c|c|c|c|c|c|}
\hline & & GLT & CLT & PSL & LSL & SWP & LVL & PW & $\begin{array}{l}\text { LDF/ } \\
\text { MDF } \\
\text { /HDF }\end{array}$ & VP & PB & OSB & LS & WPC & TM & WFI \\
\hline \multirow{2}{*}{ SLO } & \multirow{2}{*}{$\begin{array}{l}\text { points } \\
\text { ranks }\end{array}$} & 273 & 211 & 23 & 6 & 146 & 42 & 148 & 64 & 80 & 45 & 162 & 17 & 16 & 55 & 42 \\
\hline & & 1 & 2 & 12 & 15 & 5 & 10 & 4 & 7 & 6 & 9 & 3 & 13 & 14 & 8 & 10 \\
\hline \multirow{2}{*}{ CRO } & \multirow{2}{*}{$\begin{array}{c}\text { points } \\
\text { ranks }\end{array}$} & 208 & 25 & 25 & 0 & 122 & 47 & 145 & 217 & 116 & 59 & 324 & 44 & 116 & 75 & 31 \\
\hline & & 3 & 14 & 13 & 15 & 5 & 10 & 4 & 2 & 7 & 9 & 1 & 11 & 6 & 8 & 12 \\
\hline \multirow{2}{*}{ BIH } & points & 241 & 66 & 11 & 23 & 160 & 49 & 173 & 147 & 82 & 21 & 176 & 58 & 28 & 20 & 30 \\
\hline & ranks & 1 & 7 & 15 & 12 & 4 & 9 & 3 & 5 & 6 & 13 & 2 & 8 & 11 & 14 & 10 \\
\hline \multirow{2}{*}{ MK } & points & 254 & 49,5 & 45,8 & 42,1 & 237,7 & $\begin{array}{c}112, \\
3\end{array}$ & $\begin{array}{c}286 \\
8\end{array}$ & 107,4 & 98,7 & 43,6 & $\begin{array}{c}292, \\
9\end{array}$ & 74,8 & 90,3 & 98,8 & 31,5 \\
\hline & ranks & 3 & 11 & 12 & 14 & 4 & 5 & 2 & 6 & 8 & 13 & 1 & 10 & 9 & 7 & 15 \\
\hline
\end{tabular}




\subsection{Use of EWPs in Non-load and load - bearing systems}

Respondents were also asked to select building components where they specify/use EWPs in non-load bearing systems such as roofing, windows, flooring, exterior/interior surfaces and stairs (Figure 1). In Slovenia, a high level of priority in terms of the use of EWPs was noted for roofing, exterior surfaces and interiors. In Croatia, BiH and Macedonia EWP were ranked highest for interiors, followed by flooring. Use of EWPs in exterior surfaces and windows was low - respondents ranked them last. Statistically significant differences among the countries are roofing ( $p=0.013$, Fisher exact test); windows and doors $(p=0.045$, Fisher exact test); exterior surfaces ( $<<0.001$, Fisher exact test); and stairs $\mathrm{p}=0.001$, Fisher exact test).

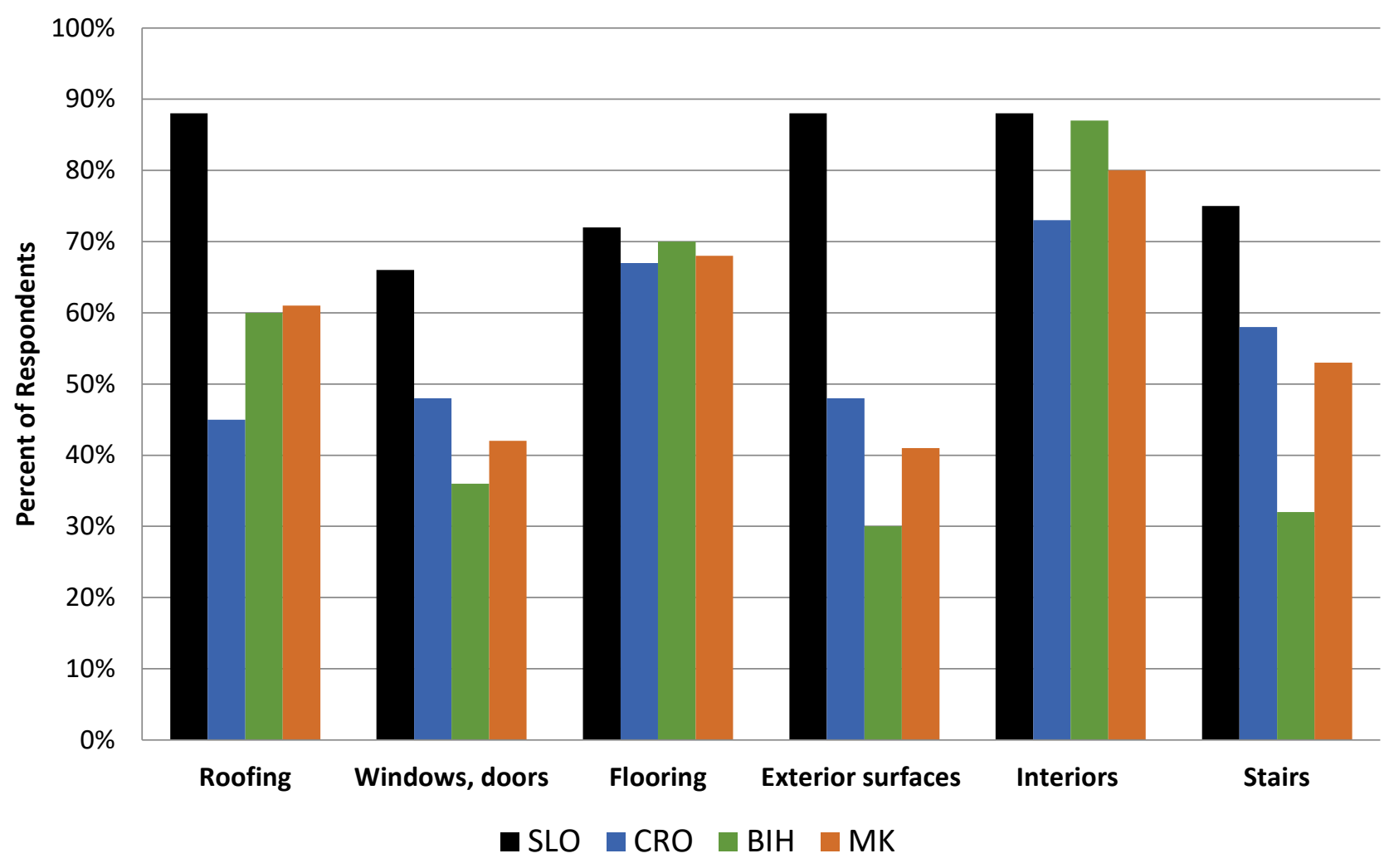

Figure 1. Respondent specification/use of EWP in non-load bearing systems

In addition, interest in the most frequently used load-bearing systems among architects in Slovenia, Croatia, $\mathrm{BiH}$ and Macedonia (Figure 2). In Slovenia, over $60 \%$ of the respondents indicated in the first place light frame and CLT, but in $\mathrm{BiH}$ respondents noted the engineering frame system, followed by light frame, and in Croatia and Macedonia the light frame followed by the engineering frame system. The share of log construction is quite high in Macedonia. Statistically significant differences between countries are by light frame/panel ( $p=0.001$, Fisher exact test); cross-laminated timber $(\mathrm{p}<0.001$, Fisher exact test); and $\log$ construction $(\mathrm{p}=0.042$, Fisher exact test). 


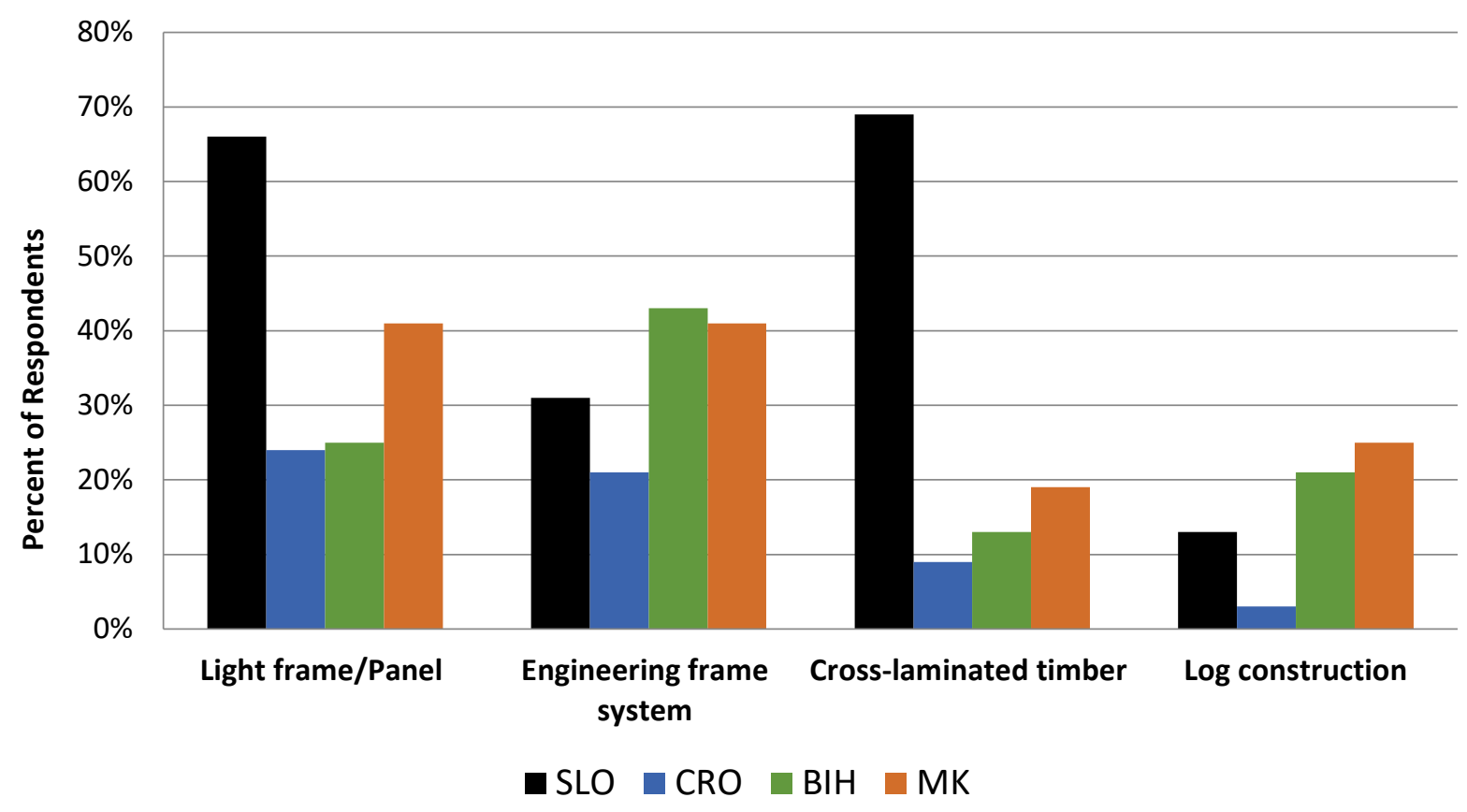

Figure 2. The specification/use of EWPs in load bearing systems

Respondents were next asked to select the type of building where they use the most EWPs (Figure 3). They reported the most usage with residential buildings (88\% Slovenia, 70\% in $\mathrm{BiH}$ and Macedonia, and 50\% in Croatia. Fewer than 10\% stated None.) However, less than $20 \%$ of Slovenian and Croatian respondents have used/specified EWP in commercial buildings, and only around 30\% $\mathrm{BiH}$ and Macedonian respondents used/specified EWP with mixed-use buildings. The proportions among the countries do not differ significantly.

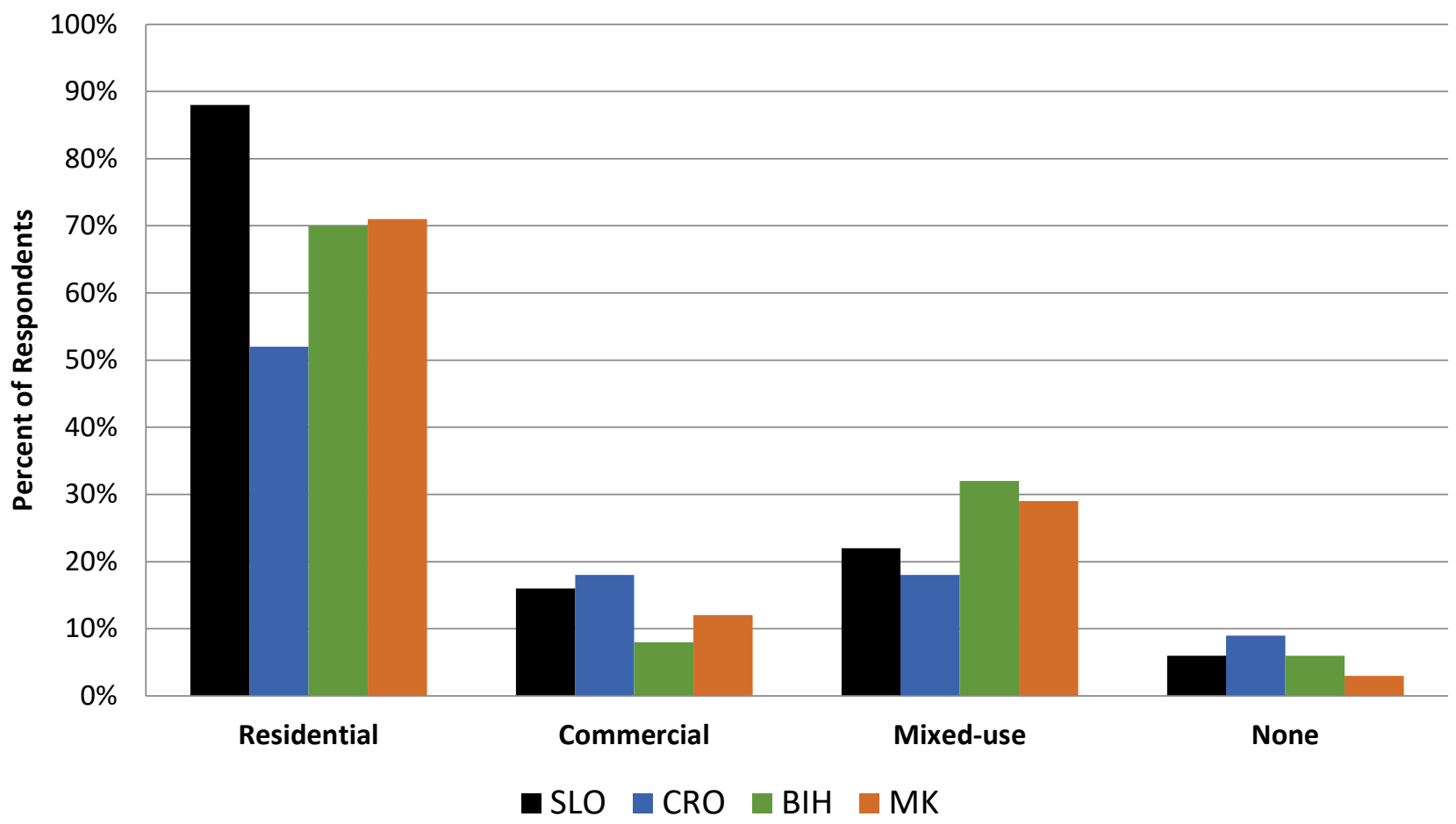

Figure 3. Usage/Specification of EWP in different types of buildings

\subsection{Information sources and needs of architects /promotional methods}


Given the importance of learning about products on the job, respondents were queried about various methods of obtaining information to support their firms and profession. Selections were made based on the following list of informational sources: Internet, from building companies, through EWPs manufacturers, through architect associations, and from homeowners. The respondents were asked to select a number from 1 to 3 , where 1 reflected the information source was not important, while $2=$ somewhat important, and $3=$ very important. Average response values by country are shown in Figure 4. In all countries, the most important informational tool is the Internet, followed by building companies and EWPs manufacturers. In Macedonia and Croatia, homeowners play an important role (ranked $4^{\text {th }}$ ). Architect associations are more important in Macedonia and $\mathrm{BiH}$ than among Slovenian and Croatian architects.

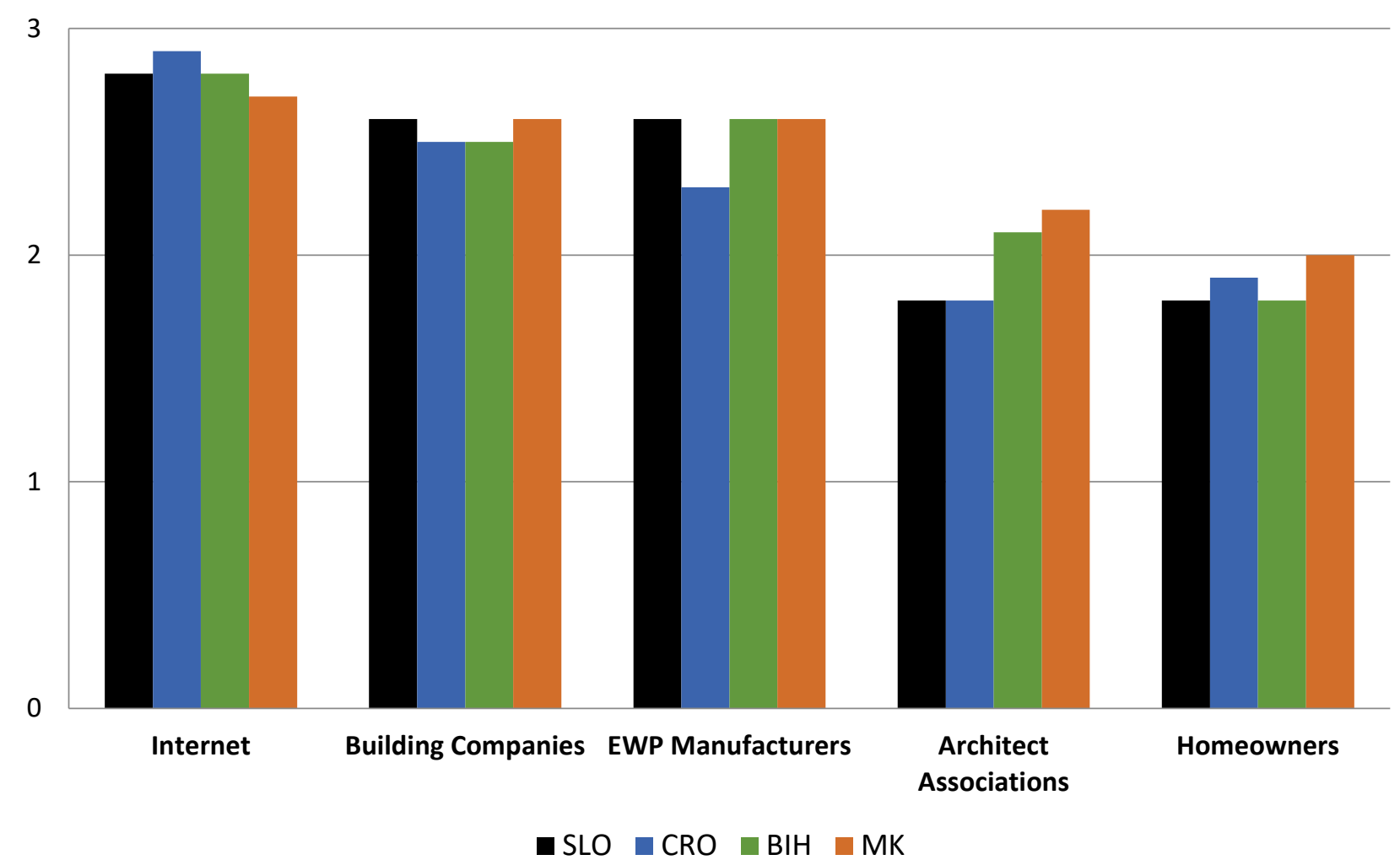

Figure 4. Importance of various information sources: 1-Not important and 3- Important

We found a negative correlation between the years of professional experience in Slovenia and the importance of architects' associations as a source of information (Spearman correlation coefficient $=-0.487, \mathrm{p}=0.005$ ), finding that less experienced architects think that architects' associations are more important source of information. The opposite was observed in Croatia, where more experienced architects think that architects' associations are a more important source of information (Spearman correlation coefficient $=0.512, \mathrm{p}=0.008$ ). $\mathrm{By} \mathrm{BiH}$ and Macedonia architects, we did not find any correlation (Figure 5). 


\section{Croatia}

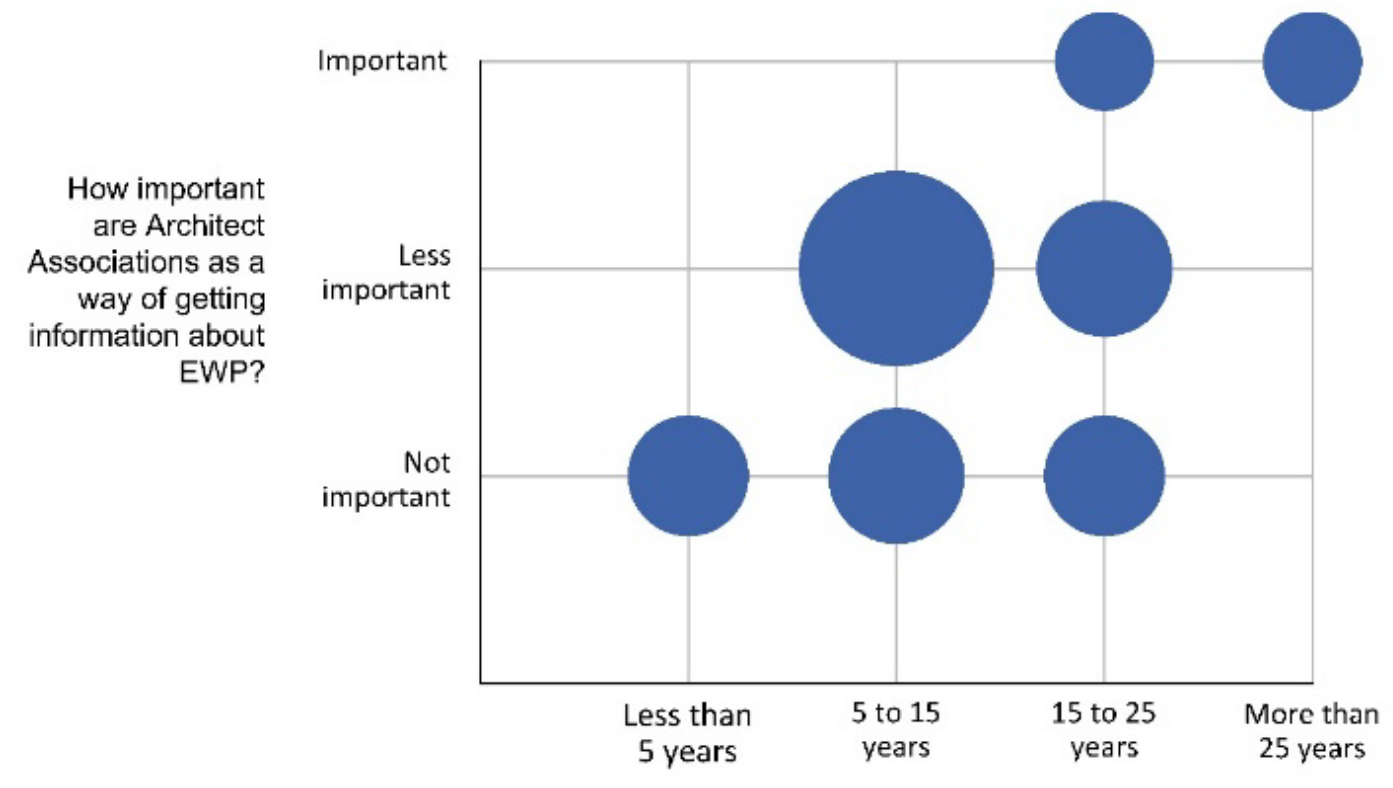

How many years of professional experience do you have?

\section{Slovenia}

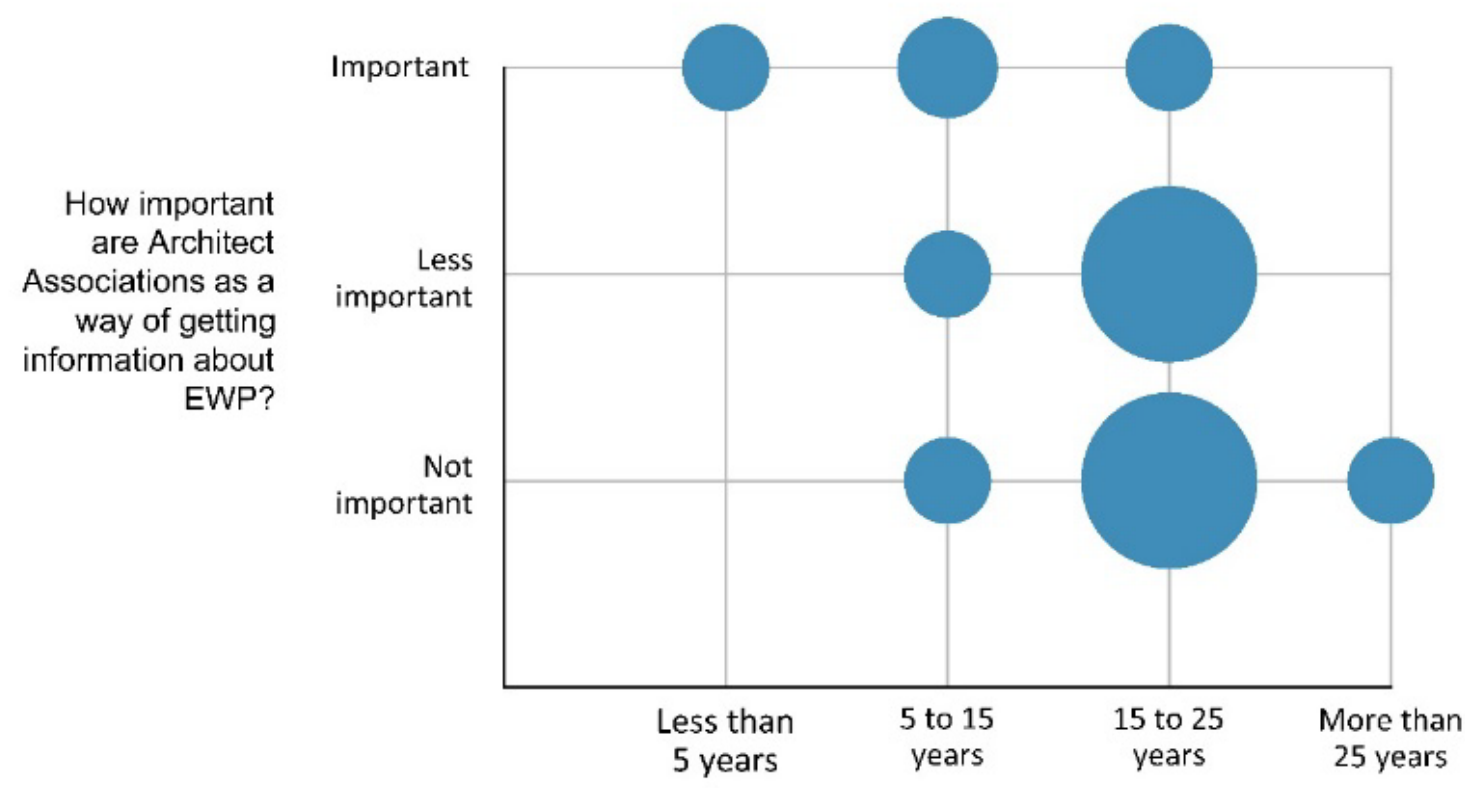

How many years of professional experience do you have?

Figure 5. Knowledge and amount of experience about EWPs in Croatia and Slovenia (the size of the bubbles represents the number of respondents.)

Respondents were also asked about the effectiveness of various information sources in terms of learning about wood and wood products relative to architectural applications. 
Specifically, they were asked to identify ways that they would like to get information about EWPs, through 1) technical specifications; 2) visits to completed structures; 3) visits to building sites under construction; and 4) direct contact with wood product manufacturers.

Respondents in all countries noted that obtaining information through technical specifications was the top rated preference, followed by visits to building sites (especially in Slovenia) and visits to completed structures (Figure 6). In last place was through direct contact with manufacturers. Each of these methods is approximately equally influential. However, a few notable differences were observed. For instance, for $\mathrm{BiH}$ architects, direct contact with manufacturers is a more important method of getting information, whereas for Croatian it is more important to visit building sites. However, there is no significant difference between the proportions reported by respondents in the different countries.

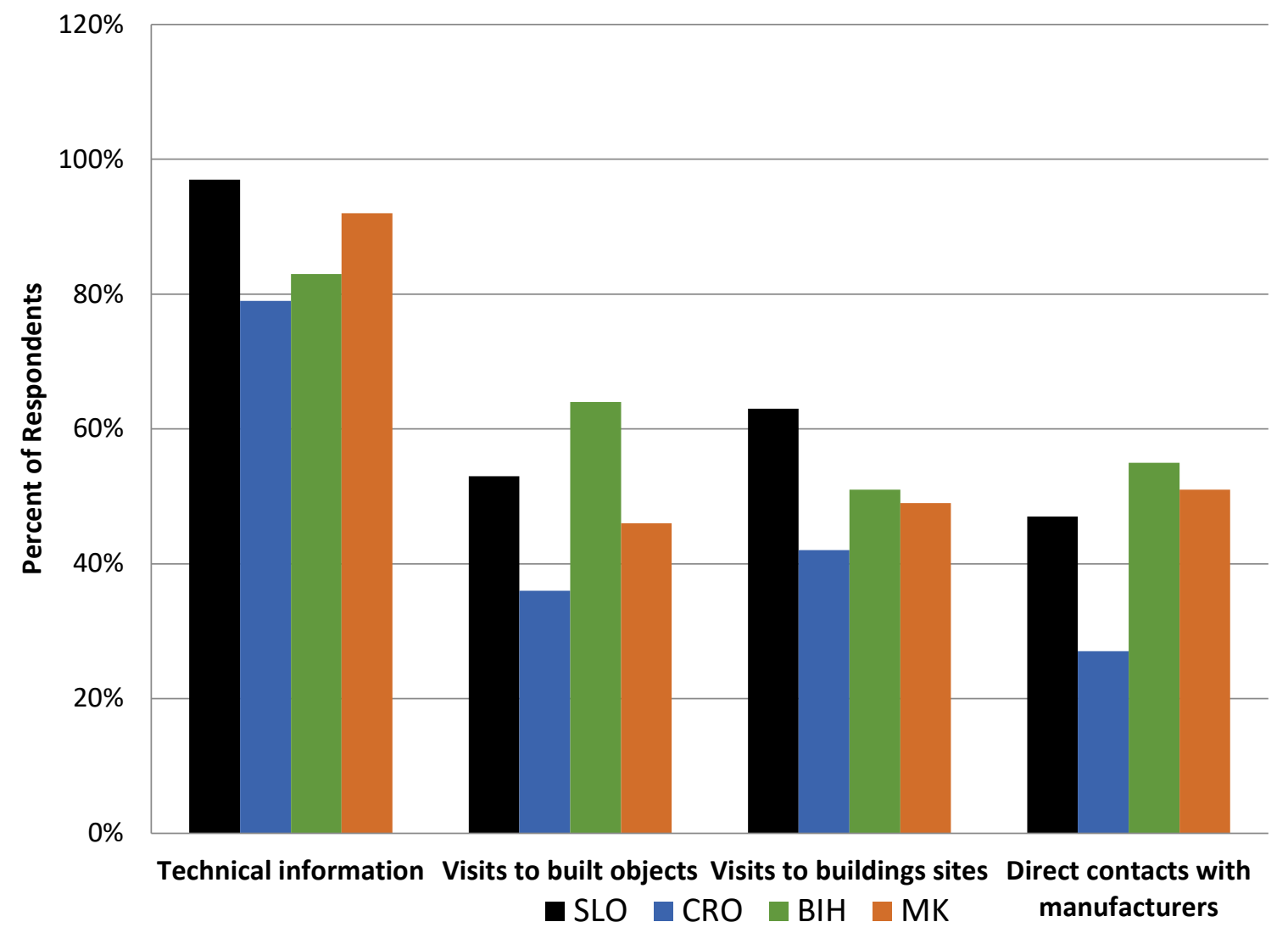

Figure 6. Information needs for EWPs

Respondents were asked if they think there has been an increased use of new EWPs in the last 5 years (Figure 7). 88\% of Slovenian respondents stated that they think their use has increased, and $13 \%$ stated that the use remained the same. $33 \%$ of Croatian respondents believed that the use of EWPs increased, while 48\% think that it remained about the same. In $\mathrm{BiH} 55 \%$ think that use increased, and $40 \%$ that it remained the same. Six percent of respondents from Croatia and $\mathrm{BiH}$ think that the use decreased. In Macedonia 35\% think that the use has increased, while more than 50\% think it remained the same. This could be in a line with Mohr and Webb [45] who point out that educating consumers about responsible product properties takes time. Therefore, investing in the availability of valid and topical information is likely to pay off only after some time [21]. Additionally, there is a statistically significant difference between countries about the increased use of new EWPs ( $<<0.001$, Fisher exact test). 


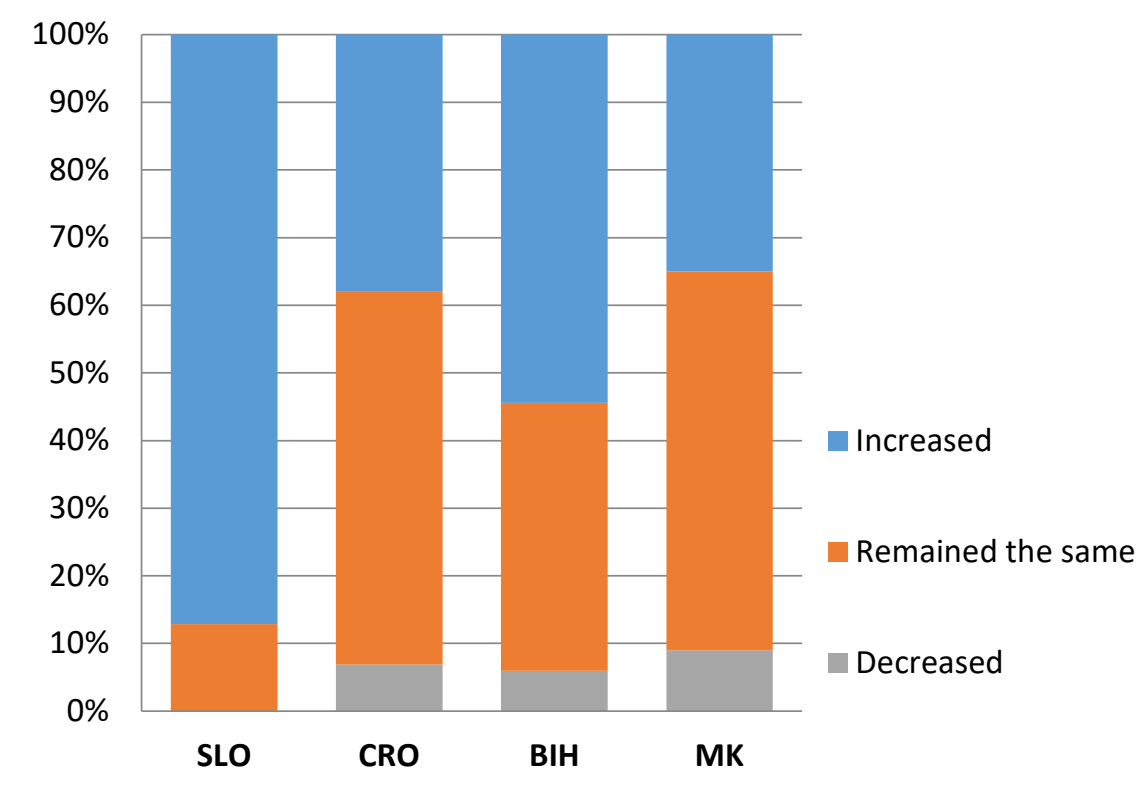

Figure 7. Respondent perceptions about usage of EWPs in the last 5 years in their countries

Finally, respondents were asked to identify their clients' perceptions of EWPs. Their responses suggest that clients in all countries generally want to have more information about EWPs. Additionally, around 30\% from Croatia and $\mathrm{BiH}$, and about $25 \%$ from Macedonia believe that their clients are not interested in EWPs, while about 10\% Slovenian customers report that their clients are adequately educated about EWPs.

\section{CONCLUSIONS AND DISCUSSION}

The objective of this study was to better understand architects' perception of EWPs and identify factors that positively contribute to the likelihood EWPs usage/specification could increase in Slovenia, Croatia, $\mathrm{BiH}$ and Macedonia. In all countries, there is a long tradition of using wood but not in structural building applications; concrete and steel continue to dominate the building industry. An online survey was conducted to collect data from over 370 respondents.

The results show that there is a positive perception in terms of familiarity with different EWPs in all 4 countries. The most common applications are structural (GLT, SWP, PW, OSB). However, differences were found among respondents when selecting the 5 most familiar EWPs. In terms of architects' opinion on whether there has been increased use of new EWPs in the last 5 years, in Slovenia, the majority agree, while in Croatia, $\mathrm{BiH}$ and Macedonia they think that it has remained the same - a finding in line with architect's experiences in timber building. There is in general a lack of knowledge of the principles of design options in using timber for structural performance. Most architects reported building residential buildings in wood, but that an era of multi-story buildings is coming in the future. The second research aimed to characterize information sources used by architects as well as the perceived value of these sources- the Internet is clearly the leading source of information.

The third objective was to characterize the information needs of architects. Respondents first note a need for more technical information to understand the potential of EWP, followed by visits to buildings sites (especially in Slovenia) and visits to build objects (in $\mathrm{BiH}$ and Macedonia). Architects could be good advocators for an increased use of EWPs but increased efforts must be placed to increase their knowledge. Demonstration projects are vital to show 
the various actors teamwork with EWP in practice; e.g. collaboration among representatives of the wood industry, architects, builders and housing associations, to better understand the technical and the business potential of wood as a multi-purpose building material. To gain more knowledge of how different parameters influence material selection and what are the drivers for EWPs in spite of conventional building materials such as steel and concrete, a more diverse group should be targeted in this region, e.g. including contractors and civil engineers.

Using the information obtained in this study will contribute to an understanding of the probability that innovative bio-based building materials with minimal environmental impact are chosen in residential and non-residential buildings, as well as high-rise buildings, and to a greater understanding of the drivers of and barriers to increased use. It is important to integrate technical specifications and also experience to ensure understanding of the functional and aesthetic performance of bio-materials over the life of a building from design to construction to use. Change is difficult - the barriers to wood are complex and the building industry is both averse to risk and slowed by inertia - but with the right focus, the wood industry can make a difference, while using EWPs can create new business opportunities for the construction industry by using validated material solutions and design tools. As the authors believe that the increased use of EWPs may be an important element of a more sustainable future built environment, more information about use and perceptions is needed.

\section{Acknowledgements}

Funding: This study was supported by the Slovenian Research Agency, Program P40015 and P4-0059. The authors would like to thank survey and interview participants who gave their time to support this study, and to the individuals and organizations who helped to distribute the survey, and the reviewers for their useful comments. 


\section{REFERENCES}

[1] M.H. Ramage, H. Burridge, M. Busse-Wicher, G. Fereday, T. Reynolds, D.U. Shah, G. $\mathrm{Wu}, \mathrm{L}$. Yu, P. Fleming, D. Densley-Tingley, The wood from the trees: The use of timber in construction, Renewable and Sustainable Energy Reviews 68 (2017) 333-359.

[2] P. Malaval, Stratégie et gestion de la marque industrielle: Produits et services business to business, Publ. Union 1998.

[3] F. Robichaud, R. Kozak, A. Richelieu, Wood use in nonresidential construction: A case for communication with architects, Forest Products Journal 59(1/2) (2009) 57-65.

[4] E. Hansen, E. Nybakk, When innovativeness determines market orientation: the forest sector and the Great Recession, BioProducts Business 1(1) (2016) 1-12.

[5] P. Dargusch, T. Maraseni, P. Schmidt, A review of research on forest-related environmental markets (including certification schemes, bioenergy, carbon markets and other ecosystem services), Plant Sciences Reviews 2010 (2011) 125-136.

[6] K. Lähtinen, T. Myllyviita, Cultural sustainability in reference to the global reporting initiative (GRI) guidelines: Case forest bioenergy production in North Karelia, Finland, Journal of Cultural Heritage Management and Sustainable Development 5(3) (2015) 290-318. [7] G. Pajchrowski, A. Noskowiak, A. Lewandowska, W. Strykowski, Wood as a building material in the light of environmental assessment of full life cycle of four buildings, Construction and building materials 52 (2014) 428-436.

[8] A. Toppinen, A. Röhr, S. Pätäri, K. Lähtinen, R. Toivonen, The future of wooden multistory construction in the forest bioeconomy - A Delphi study from Finland and Sweden, Journal of Forest Economics (2018) In Press.

[9] O. Høibø, E. Hansen, E. Nybakk, Building material preferences with a focus on wood in urban housing: durability and environmental impacts, Canadian Journal of Forest Research 45(11) (2015) 1617-1627.

[10] M. Kitek Kuzman, D. Sandberg, A new Era for Multi-Storey Timber Buildings in Europe'In: 70th FPS International convention June 27-29, Portland, US (2016).

[11] M. Kitek Kuzman, D. Sandberg, Comparison of timber-house technologies and initiatives supporting use of timber in Slovenia and in Sweden-the state of the art, iForestBiogeosciences and Forestry 10(6) (2017) 930-938.

[12] K. Jones, J. Stegemann, J. Sykes, P. Winslow, Adoption of unconventional approaches in construction: The case of cross-laminated timber, Construction and Building Materials 125 (2016) 690-702.

[13] T. Nord, Prefabrication strategies in the timber housing industry: a comparison of Swedish and Austrian markets, Luleå tekniska universitet, 2008.

[14] E. Hurmekoski, R. Jonsson, T. Nord, Context, drivers, and future potential for woodframe multi-story construction in Europe, Technological forecasting and social change 99 (2015) 181-196.

[15] A. Sinha, R. Gupta, A. Kutnar, Sustainable Development and Green Buildings, Wood Industry/Drvna Industrija 64(1) (2013) 45-53.

[16] R.A. Kozak, D.H. Cohen, An analysis of the North American specifiers of structural materials in non-residential construction, Centre for Advanced Wood Processing, Vancouver, 1996.

[17] M.F. Ashby, K. Johnson, Materials and design: the art and science of material selection in product design, Elsevier, Oxford, 2002.

[18] D. Sandberg, Additives in Wood Products-Today and Future Development, Environmental Impacts of Traditional and Innovative Forest-based Bioproducts, Springer2016, pp. 105-172. 
[19] T. Amberla, L. Wang, H. Juslin, R. Panwar, E. Hansen, R. Anderson, Students' perceptions of forest industries business ethics-A comparative analysis of Finland and the USA, EJBO-Electronic Journal of Business Ethics and Organization Studies (2010).

[20] R.M. Toivonen, Product quality and value from consumer perspective-An application to wooden products, Journal of Forest Economics 18(2) (2012) 157-173.

[21] A. Toppinen, R. Toivonen, A. Valkeapää, A. Rämö, Consumer perceptions of environmental and social sustainability of wood products in the Finnish market, Scandinavian journal of forest research 28(8) (2013) 775-783.

[22] K. Lähtinen, T. Myllyviita, P. Leskinen, S.K. Pitkänen, A systematic literature review on indicators to assess local sustainability of forest energy production, Renewable and Sustainable Energy Reviews 40 (2014) 1202-1216.

[23] V.-S. Osburg, M. Strack, W. Toporowski, Consumer acceptance of wood-polymer composites: a conjoint analytical approach with a focus on innovative and environmentally concerned consumers, Journal of Cleaner Production 110 (2016) 180-190.

[24] L. Wang, A. Toppinen, H. Juslin, Use of wood in green building: a study of expert perspectives from the UK, Journal of cleaner production 65 (2014) 350-361.

[25] A. Roos, M. Lindström, L. Heuts, N. Hylander, E. Lind, C. Nielsen, Innovation diffusion of new wood-based materials-reducing the "time to market", Scandinavian journal of forest research 29(4) (2014) 394-401.

[26] R.A. Kozak, D.H. Cohen, How specifiers learn about structural materials, Wood and fiber science 29(4) (2007) 381-396.

[27] R.A. Kozak, D.H. Cohen, Architects and structural engineers: An examination of wood design and use in nonresidential construction, Forest products journal 49(4) (1999) 37.

[28] C.W. Gaston, Visual wood product trends in North American nonresidential buildings, Forest products journal 64(3) (2014) 107-115.

[29] J. O'Connor, R. Kozak, C. Gaston, D. Fell, Wood use in nonresidential buildings: opportunities and barriers, Forest products journal 54(3) (2004) 19-28.

[30] A. Roos, L. Woxblom, D. McCluskey, The influence of architects and structural engineers on timber in construction-perceptions and roles, Silva Fennica 44(5) (2010) 871884.

[31] M. Kitek Kuzman, A. Kutnar, Contemporary Slovenian timber architecture for sustainability, Springer International Publishing, 2014.

[32] S. Klarić, Održivo stanovanje, drvo, ovčja vuna, slama izazovi i potencijali tradicionalnih prirodnih materijala, Internacionalni BURCH Univerzitet 2015.

[33] M. Kitek Kuzman, Wood in Contemporary Slovenian Architecture 2010-2015, University of Ljubljana, Biotechnical faculty, Department of Wood Science and Technology, Ljubljana, 2015.

[34] E.R. Wagner, E.N. Hansen, Environmental attributes of wood products: Context and relevance for US architects, Forest products journal 54(1) (2004) 19-25.

[35] K. Hemström, K. Mahapatra, L. Gustavsson, Perceptions, attitudes and interest of Swedish architects towards the use of wood frames in multi-storey buildings, Resources, conservation and recycling 55(11) (2011) 1013-1021.

[36] T. Bowers, I. Ganguly, I. Eastin, Eco-labeled wood products in the us residential construction industry: Architects' awareness and usage of certified wood and green building programs, The Forestry Chronicle 90(5) (2014) 605-613.

[37] D. Motik, A. Pirc, A. Kruljac, The attitudes of participants in the chain of wood products use, Wood processing and furniture manufacturing: present conditions, opportunities and new challenges,, Vyhne, Slovak Republic, 2010, International Association for Economics and Management in Wood Processing and Furniture Manufacturing-WoodEMA, ia, 2010. 
[38] N. Li, A. Toppinen, Corporate responsibility and sustainable competitive advantage in forest-based industry: Complementary or conflicting goals?, Forest Policy and Economics 13(2) (2011) 113-123.

[39] M. Praznik, V. Butala, M.Z. Senegačnik, Simplified evaluation method for energy efficiency in single-family houses using key quality parameters, Energy and buildings 67 (2013) 489-499.

[40] A. Pirc Barčić, D. Motik, L. Oblak, R. Vlosky, Management activity linkages to innovation deconstruction: An exploratory study of the furniture industry in Croatia, BioResources 11(2) (2016) 3987-4005.

[41] D.T. Damery, P. Fisette, Decision making in the purchase of siding: A survey of architects, contractors, and homeowners in the US northeast, Forest Products Journal 51(7/8) (2001) 29-36.

[42] D.A. Dillman, Mail and Internet surveys: The tailored design method--2007 Update with new Internet, visual, and mixed-mode guide, John Wiley \& Sons 2011.

[43] W. Fan, Z. Yan, Factors affecting response rates of the web survey: A systematic review, Computers in human behavior 26(2) (2010) 132-139.

[44] R. Polikar, Ensemble based systems in decision making, IEEE Circuits and Systems Magazine 6(3) (2006) 21-45.

[45] L.A. Mohr, D.J. Webb, The effects of corporate social responsibility and price on consumer responses, Journal of Consumer Affairs 39(1) (2005) 121-147. 